\title{
Side effects that Cause Noncompliance to Antidepressant Medications in the Course of Outpatient Treatment
}

\author{
Adem Balikci', Ozcan Uzun², Murat Erdem³ ${ }^{3}$ Ali Doruk ${ }^{4}$, Adnan Cansever ${ }^{4}$, Mehmet Alpay Ates ${ }^{5}$
}

\section{ÖZET:}

Ayaktan izlenen hastalarda antidepresan tedaviye uyunçu bozan ilaç yan etkileri

Amaç: Tedaviye uyunçsuzluk, hekimin önerdiği tedavi programını hastanın yerine getirmemesi olarak tanımlanır. Yapılan çalışmalarda selektif serotonin geri alım inhibitörleri (SSGI) ve trisiklik antidepresanlar (TSA) için ilaç uyunçsuzluğu oranının \%21-60 arasında olduğu saptanmıştır. İlaç yan etkisi uyunçsuzluk nedenlerinin yaklaşık \%30'undan sorumlu bulunmuştur. Bu çalışmada SSGI ve TSA kullanan olgularda ilaç uyunçsuzluğuna neden olan yan etkilerin saptanması amaçlanmıştır.

Yöntem: Çalışmaya GATA Psikiyatri A.D. polikliniğine başvuran, tedaviye uyunçsuzluğu saptanan, SSGI veya TSA kullanan 264 olgu alındı. Olguların sosyodemografik özellikleri, kullandığı ilaçlar ve uyunçsuzluk nedenleri yarı yapılandırımış bir anketle değerlendirildi.

Bulgular: Olguların 71'inin (\%26.8) yan etkiler nedeniyle tedaviye uyuncunun bozulduğu saptandı. SSGI ve TSA grupları arasında yaş, eğitim düzeyi ve cinsiyet yönünden fark saptanmamıştır. TSA grubunda somatizasyon bozukluğu tanısı alanlarda yan etkiler nedeniyle tedaviyi bırakma oranı daha yüksek bulunmuştur. Bunun dışında her iki grubun kendi içerisinde de yan etkiler nedeniyle tedaviyi bırakma ve diğer nedenlere bağlı tedaviyi bırakma açısından da fark bulunmamıştır.

Sonuç: Bu çalışmada yan etkilerin neden olduğu ilaç uyunçsuzluğu yönünden iki grup arasında anlamlı farklılık bulunmamıştır. Uyunçsuzluğun önlenmesinde, kullanılan antidepresanın değiştirilmesinin veya hastaların bilgilendirilmesinin etkili olabileceği düşünülmüştür.

Anahtar sözcükler: antidepresif ajanlar, uyunç, yan etki

Klinik Psikofarmakoloji Bulteni 2014;24(1):69-75

\section{ABSTRACT:}

Side effects that cause noncompliance to antidepressant medications in the course of outpatient treatment

Objective: Treatment non-compliance is defined as patients not following the treatment program as recommended by their physician. In studies, drug noncompliance for selective serotonin reuptake inhibitors (SSRIs) and tricyclic antidepressants (TCAs) has been found to be between $21-60 \%$. Pharmacotherapeutic side effects were found to be responsible for approximately $30 \%$ of cases of non-compliance. In this study, we aimed to determine side effects that cause noncompliance in patients using SSRIs and TCAs.

Method: The study group consisted of 264 patients, who were admitted to GATA Psychiatry outpatient clinic, in whom noncompliance was identified and who were using either SSRI or TCA treatments. Sociodemographic characteristics of the cases, medications they had used and causes of non-compliance were evaluated with a semistructured questionnaire.

Results: It was found that 71 of the cases (26.8\%) had discontinued the treatment due to side effects. No differences were found in terms of gender, age or educational level between the SSRI and TCA groups. The discontinuation rate due to side effects was higher in the somatization disorder subgroup medicated with TCAs. Moreover, there were no differrences within both groups with respect to discontinuation due to side effects or other causes.

Conclusion: In this study, no significant differences were found between the two groups with respect to side effects that cause medication non-compliance. It was concluded that switching to another medication or informing patients adequately should be effective for prevention of noncompliance.

Keywords: antidepressive agents, compliance, adverse effects

Bulletin of Clinical Psychopharmacology 2014;24(1):69-75
'M.D., Samsun Military Hospital, Samsun - Turkey ${ }^{2}$ Prof., ${ }^{3}$ Assist. Prof., ${ }^{4}$ Assoc. Prof., Gulhane Military Medical Faculty, Department of Psychiatry, Ankara - Turkey

${ }^{5}$ Assoc. Prof., GATA Haydarpasa Psychiatry Training Hospital, Department of Psychiatry, Istanbul - Turkey

Address reprint requests to: Dr. Adem Balikci, Gülhane Askeri Tıp Akademisi Ruh Sağlığı ve Hastalıkları Anabilim Dalı Etlik, Keçiören, Ankara - Turkey

E-mail address:

balikciadem@yahoo.com

Date of submission:

April 06, 2011

Date of acceptance: August 27, 2012

Declaration of interest:

A.B., O.U., M.E., A.D., A.C., M.A.A.: The authors reported no conflict of interest related to this article. 


\section{INTRODUCTION}

The efficacy of pharmacological therapies and psychotherapy in the treatment of depression and anxiety disorders has been proven ${ }^{1}$. Even though there is a large number of patients all over the world and a high prevalence of these diseases $^{2-4}$, the most common first and second line treatment methods are antidepressant drugs for a number of reasons such as lack of personnel skilled in providing psychotherapy, economic reasons and limitations of time and space. The use of antidepressants has increased dramatically in many western countries in the last 20 years $^{1}$. In particular, selective serotonin reuptake inhibitors (SSRI) and the newgeneration antidepressants are being prescribed intensively ${ }^{5}$. The sales of tricyclic antidepressants (TCAs) have been reduced while sales of SSRIs have increased in the last twenty years in the Nordic countries ${ }^{6}$. However, TCAs are still being used extensively worldwide ${ }^{7}$. SSRI agents are generally better tolerated than TCAs and both groups are thought to have nearly the same level of activity ${ }^{8}$.

Treatment non-compliance is defined as patients not fulfilling the treatment program as recommended by their physician. Noncompliance leads to negative consequences such as the emergence of new episodes, prolongation of treatment, higher hospitalization rates, loss of labor and increased $\operatorname{cost}^{9-11}$. Metaanalyses have shown that the rate of noncompliance varied between $21-60 \%$ for SSRIs and $\mathrm{TCAs}^{9,12,13}$. Of patients starting therapy with an antidepressant, 30-83\% discontinue the treatment without consulting a physician because of many factors such as physician-patient communication, family support, clinical response to treatment and side effects ${ }^{14-16}$. Side effects associated with the use of medications have been found to be responsible for approximately $30 \%$ of all noncompliance cases ${ }^{12,13}$. In one study, it was found that at least half of the patients, who had been using SSRIs were found to have side-effects, which may cause problems ${ }^{16}$. In this study, we aimed to identify side effects that cause noncompliance and also to find out the differences between two groups using either SSRIs or TCAs in an outpatients population.

\section{METHODS}

\section{Selection and Description of Cases}

A total of 264 patients (134 men, 130 women) who were admitted to GMMF Department of Psychiatry between the years 2004-2005, whose antidepressant treatment was initiated for treatment of depression $(n=108)$, anxiety $(n=135)$, or somatization $(n=21)$ but who quit treatment without consent of a physician or any control were included in the study. Before leaving treatment 166 of these cases were using SSRIs and 98 were using TCAs.

A demographic data form was completed during face to face interviews with the patients. Sociodemographic characteristics of cases, medications and treatment protocols were assessed with a semi-structured questionnaire which included the reasons for non-compliance and how long the patient stayed on the prescribed treatment. Medications were evaluated in two main groups (TCAs and SSRIs) s and sub-groups were defined according to the patients' diagnoses. In order to identify the effect of medication-related side effects, causes for discontinuation were classified as "adverse events" and others". No stand alone evaluation was made based on the active ingredients of the medications and the dosage.

\section{Exclusion Criteria}

Patients with non-mental chronic medical diseases (paraplegia, osteoarthritis, heart failure, etc.) that may affect social functioning, dementia, mental retardation, epilepsy, neurological diseases that could cause organic brain disorder such as head trauma, substance abuse other than smoking and pregnant women were excluded from the study. 


\section{Statistics}

Analyzes were performed with SPSS 15.0 software. Frequency, percentage, mean and standard deviation were taken as descriptive statistics. After studying the data for normal distribution with the Kolmogorov-Smirnov test, the Student t test was used for continuous variables, which were found to comply with a normal distribution and the Mann-Whitney $U$ test was used for data that did not conform to the normal distribution criteria. The Chi-Square test was used to compare discrete variables. For statistical significance, $\mathrm{p}<0.05$ was adopted.

\section{RESULTS}

It was found that 194 of patients $(73.2 \%)$ had treatment non-compliance due to a variety of reasons such as inadequate effect of medication, patient or disease characteristics and doctorpatient relationship and $71(26.8 \%)$ had noncompliance due to side effects. Twenty out of 98 patients $(20.4 \%)$ in the TCA group and 51 among 166 patients $(30.7 \%)$ in the SSRI group quit the treatment due to side effects of the drug. No difference was found in terms of discontinuation rates due to adverse events between the two groups $\left(\chi^{2}=3.23, \mathrm{p}=0.07\right)$.

Comparison of the sociodemographic and clinical aspects of patients who discontinued treatment due to adverse effects in both groups is given in Table 1. No difference was found in terms of age, educational level and gender between groups. When patients who discontinued treatment due to side effects or other reasons were compared within and between the two groups, the rate of discontinuation due to side effects was found to be higher than the rate of discontinuation due to other causes in patients with the diagnosis of somatization disorder in the TCA group $(\mathrm{p}=0.013)$.

Figure 1 shows side effects of medications that caused discontinuation in the SSRI and TCA groups. Side effects that caused non-compliance were found to be weight gain (7.5\%), anxiety (4.9\%), sexual problems $(4.9 \%)$, dizziness $(4.9 \%)$, insomnia $(3.0 \%)$, nausea $(3.0 \%)$, sedation $(2.6 \%)$, pruritus $(2.3 \%)$, increased appetite $(1.1 \%)$ and constipation $(1.1 \%)$. TCAs caused sedation, constipation, and palpitations and SSRIs caused insomnia, anxiety and nausea at significantly higher rates $(\mathrm{p}<0.05)$.

No difference was detected in terms of duration of treatment between groups $(\mathrm{p}=0.842)$. In addition, percentages of individual side effects showed no difference in the first 3 months and after 3 months in the group that discontinued treatment due to side effects associated with the use of medications (Figure 2).

Table 1: Comparison of sociodemographic features and diagnosis of cases that discontinued treatment due to drug side effects and other reasons TCA and SSRI groups.

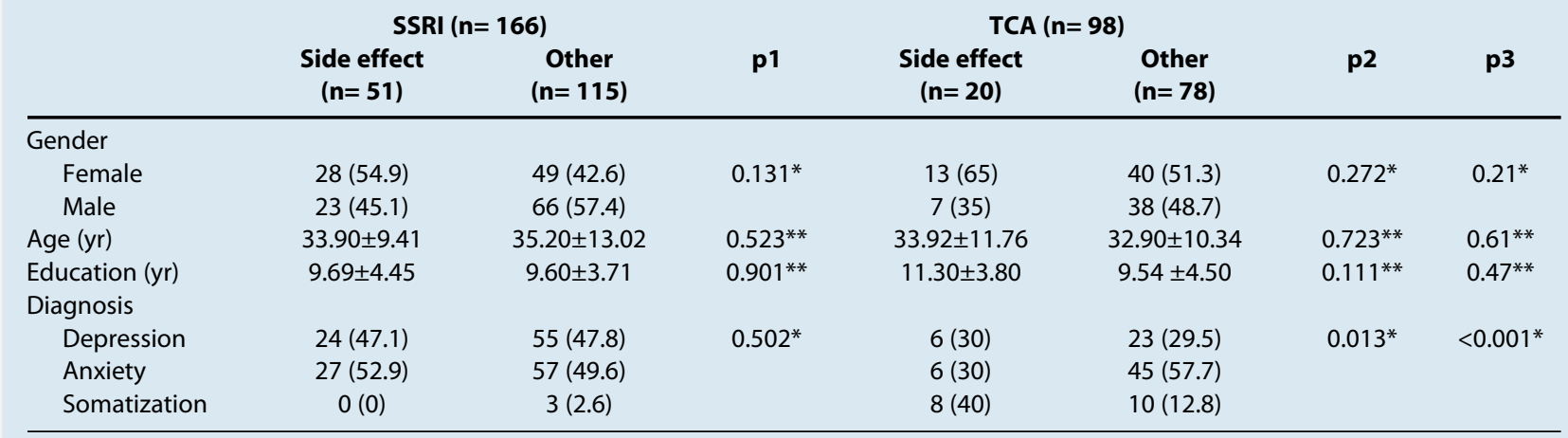

$\mathrm{p} 1$ : Comparison of cases that dropped-out of treatment due to drug side effects and other reasons in the SSRI group. p2: Comparison of cases that dropped-out of treatment due to drug side effects and other reasons in the TCA group. p3: Comparison of SSRI and TCA groups.

*: Chi-square test, ${ }^{* *}$ Student $t$ test 


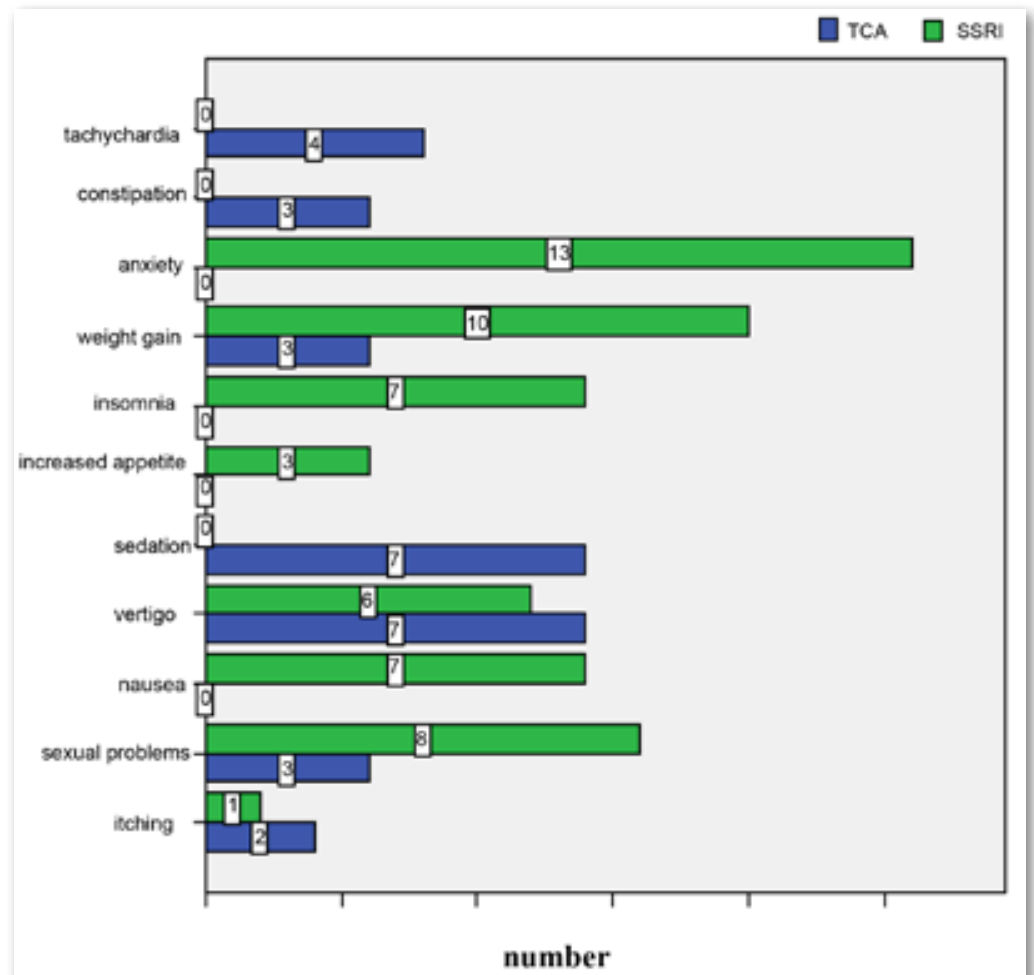

Figure 1: Drug side effects that cause non-compliance in the SSRI and TCA groups.

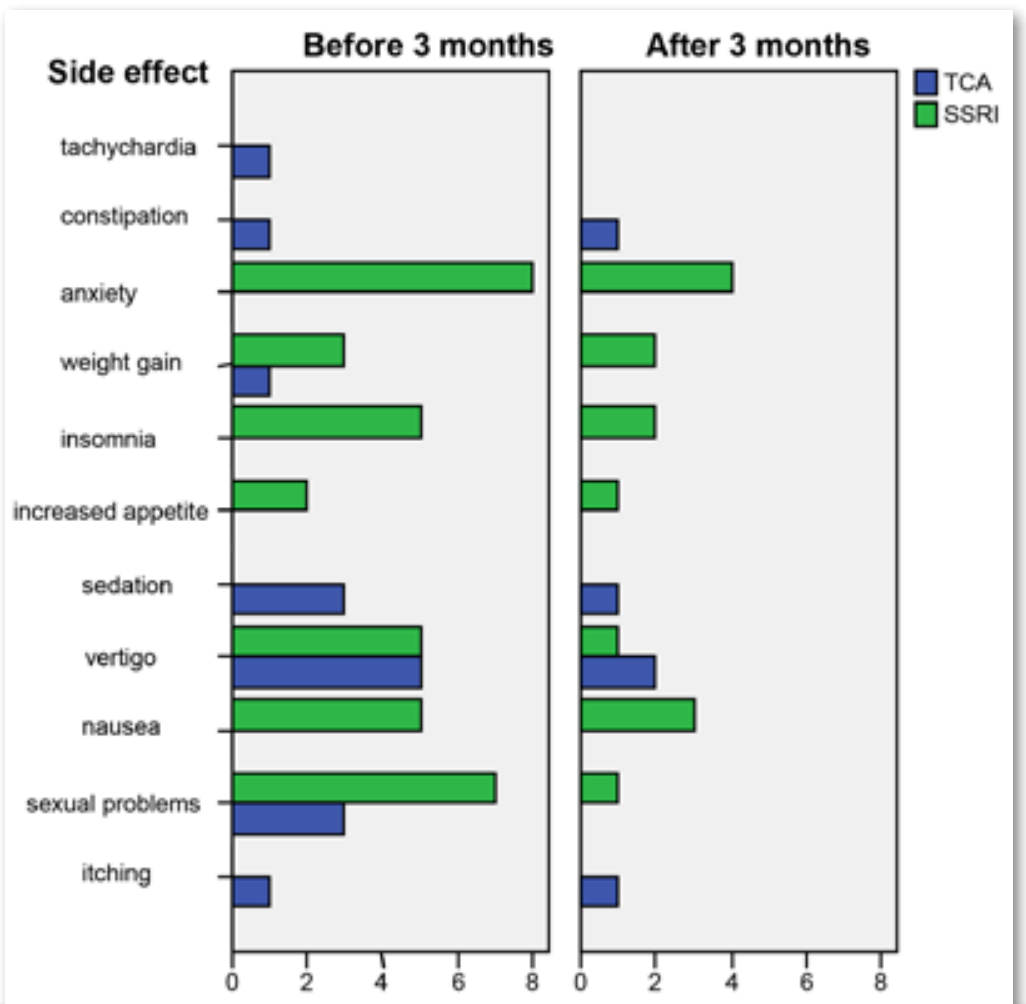

Figure 2: Side effects according to duration of non-compliance in the TCA and SSRI groups. 


\section{DISCUSSION}

The aim of this study was to determine the side effects, which disrupt compliance to antidepressant treatment and to compare the SSRI and TCA groups. In this study, it was found that treatment compliance was impaired in $26.8 \%$ of patients due to side effects. The discontinuation rate due to side effects was similar to some previous studies (16). In a study evaluating 401 patients it was found to be $36 \%$. No difference was found in terms of age, educational level and gender between the subgroup of drop-outs due to side effects and the subgroup of drop-outs due to other reasons.

In our study, side effects that caused noncompliance were found to be weight gain (7.5\%), anxiety $(4.9 \%)$, sexual problems $(4.9 \%)$, dizziness $(4.9 \%)$, insomnia $(3.0 \%)$, nausea $(3.0 \%)$, sedation $(2.6 \%)$, pruritus $(2.3 \%)$, increased appetite $(1.1 \%)$ and constipation (1.1\%). TCAs caused sedation, constipation, and palpitation and SSRIs caused insomnia, anxiety and nausea at significantly higher rates. These side effects of TCAs, which occured more often than placebo and SSRIs, were also found in previous studies ${ }^{17}$.

Sedation, orthostatic hypotension and anticholinergic side effects have been reported to be higher with TCAs than SSRIs in many studies $^{18,19}$. These side effects are related to receptor interaction profiles of antidepressants and they may also differ within the drug groups ${ }^{19}$. In a meta-analysis of 11 studies with a total of 601 patients, dry mouth, constipation, diarrhea, drowsiness, lethargy, dizziness, anorexia, tremor and sweating were more common with TCAs while nausea/vomiting and sleep disorders were reported more frequently with SSRIs. This study indicates the difference in the side effect profile between the two groups. In this study, the TCAs were associated with a higher rate of medication drop-out ${ }^{20}$.

The side effects of SSRIs that were found to be more frequent in our study (insomnia, anxiety, and nausea) have been highlighted in previous studies. In general, gastrointestinal problems, headache, sedation, insomnia, activation, parethesis and sexual side effects are often reported in the acute period of SSRI treatment ${ }^{18}$. The point to be considered here is, although many studies have reported rates of adverse events, in our study, only the rates of discontinuation due to side effects was stated.

In our study, the most common side effect that caused non-compliance was weight gain $(7.5 \%)$. Previous studies have emphasized that risks of weight gain associated with the use of medications are different. Relative risks of antidepressants in terms of weight gain may have large differences within the same drug group. In general, SSRIs also cause sexual dysfunction and weight gain more commonly, when compared with atypical antidepressants (eg, bupropion and nefazodone) ${ }^{18}$.

Rates of sexual side effects have been reported to be between $25-50 \%$ in many studies. In our study, withdrawal rate due to these adverse events was found to be $4.9 \%$. This may be related to development of tolerance to many side effects over time or the difference in short- and long-term consequences of adverse effects. Weight gain and sexual side effects have been reported to have an increasing importance, especially during the maintenance period ${ }^{21}$.

The American Psychiatric Association (APA) recommends to maintain acute treatment of depression for 6 to 8 weeks and to continue treatment for 4-9 months after the symptoms have resolved in order to ensure complete remission and to avoid relapses ${ }^{22}$. However, many patients leave treatment early (before 3 months). Discontinuation rates in the first 3 months can increase up to $70 \%$ depending on the prescribed antidepressant and the patient population ${ }^{16}$. Leaving treatment is largely seen in the first month. In one study, $28 \%$ of patients left treatment within the first month and $44 \%$ within the first 3 months ${ }^{22}$. In our study, the highest rate of discontinuation due to adverse events was recorded within the first month.

This finding is also consistent with previous studies. In a study with patients in primary care, who had been prescribed tricyclic antidepressants, 
$21 \%$ of the patients dropped-out within the first 2 weeks of treatment and $10 \%$ of the rest droppedout in each subsequent two-week period; as a result, only half of them were on treatment after 4 months ${ }^{23}$. In a study of a large sample, discontinuation due to adverse events was found to be significantly higher in patients using highdose TCA than users of low-dose ${ }^{7}$. When studies are evaluated as a whole, it is a common consideration that, in addition to the patient's justification, cessation of treatment in the early period of treatment (before 3 months) is also related to side-effects.

As a result, although the two groups had

\section{References:}

1. Cetin M, Acikel C. In perspective of meta-analyses: Are all of the antidepressants similar? Klinik Psikofarmakoloji Bulteni - Bulletin of Clinical Psychopharmacology 2009;19(2):87-92. (Turkish)

2. Trivedi MH. Treating depression to full remission. J Clin Psychiatry 2009;70(1):01. [CrossRef]

3. Kulaksizoglu IB. Mood and anxiety disorders in patients with myasthenia gravis: aetiology, diagnosis and treatment. CNS Drugs 2007;21(6):473-81. [CrossRef]

4. Cirakoglu OC, Uluc S, Uluc BN. How do university students perceive depressive symptoms? A qualitative study on perceived causes, cures and helping behaviours of depression. TAF Prev Med Bull. 2008;7(2):119-26.

5. Onur E, Yemez B, Polat S, Gurz NY, Cimilli C. Change in the preference of the psychotropic drugs and consultation liaison psychiatry practice. Klinik Psikofarmakoloji Bülteni Bulletin of clinical psychopharmacology 2007;17(4):167-73. (Turkish)

6. Zahl PH, De Leo D, Ekeberg Ø, Hjelmeland H, Dieserud $\mathrm{G}$. The relationship between sales of selective serotonin reuptake inhibitor, tricyclic antidepressant and suicide rates in the Nordic countries. BMC Psychiatry 2010:10:62.

7. Furukawa TA, McGuire H, Barbui C. Meta-analysis of effects and side effects of low dosage tricyclic antidepressants in depression: systematic review. BMJ 2002;325(7371):991. [CrossRef]

8. Cipriani A, Barbui C, Brambilla P, Furukawa TA, Hotopf M, Geddes JR. Are all antidepressants really the same? The case of fluoksetine: a systematic review. J Clin Psychiatry 2006;67(6):850-64. [CrossRef]

9. Martin RM, Hilton SR, Kerry SM, Richards NM. General practitioners' perceptions of the tolerability of antidepressant drugs: a comparison of selective serotonin reuptake inhibitors and tricyclic antidepressants. BMJ. 1997;314(7081):646-51. [CrossRef] different side effect profiles and showed no significant difference in terms of the consequences of side effects on treatment, discontinuation is an important finding. Collection of data non-specific to individual drug substance and dose is a limitation of our study. Although we detected a significant difference related to somatization disorder, studying this difference in a more homogeneous and wide group would be advisable. In the future, it would be useful to conduct larger studies evaluating drug doses, drugs in each group and diagnostic groups separately. It may be useful to switch medications and inform patients to prevent non-compliance.

10. Delgado PL. Approaches to the enhancement of patient adherence to antidepressant medication treatment. J Clin Psychiatry 2000;61(Suppl 2):S6-S9.

11. Demyttenaere K. Noncompliance with antidepressants: who's to blame? Int Clin Psychopharmacol 1998;13 (Suppl2):S19-S25. [CrossRef]

12. Song F, Freemantle N, Sheldon TA, House A, Watson P, Long A, et al. Selective serotonin reuptake inhibitors: meta-analysis of efficacy and acceptability. BMJ 1993;306(6879):683-7. [CrossRef]

13. Anderson IM, Tomenson BM. Treatment discontinuation with selective serotonin reuptake inhibitors compared with tricyclic antidepressants: a meta-analysis. BMJ 1995;310 (6992):1433-38. [CrossRef]

14. Melfi CA, Chawla AJ, Croghan TW, Hanna MP, Kennedy S, Sredl K. The effects of adherence to antidepressant treatment guidelines on relapse and recurrence of depression. Arch Gen Psychiatry 1998;55(12):1128-32. [CrossRef]

15. Bultman DC, Svarstad BL. Effects of pharmacist monitoring on patient satisfaction with antidepressant medication therapy. J Am Pharm Assoc (Wash) 2002;42(1):36-43. [CrossRef]

16. Bull SA, Hu H, Hunkeler EM, Lee JY, Ming EE, Markson LE, et al. Discontinuation of use and switching of antidepressants. JAMA 2002;288(11):1403-9. [CrossRef]

17. Jackson JL, Shimeall W, Sessums L, Dezee KJ, Becher D, Diemer M, et al. Tricyclic antidepressants and headaches: systematic review and meta-analysis. BMJ 2010;341:c5222. [CrossRef]

18. Cassano P, Fava M. Tolerability Issues During Long-Term Treatment with Antidepressants. Ann Clin Psychiatry 2004;16(1):15-25. [CrossRef] 
19. Huszonek JJ, Dewan MJ, Koss MH, William J, Ispahani A. Antidepressant Side Effects and Physician Prescribing Patterns. Ann Clin Psychiatry 1993(1);5:7-11. [CrossRef]

20. Wilson K, Mottram PA. Comparison of selective serotonin reuptake inhibitors and tricyclic antidepressants in older depressed patients: a meta-analysis. Int J Geriatr Psychiatry 2004;19(8):754-62. [CrossRef]

21. Masand PS, Gupta S. Long-Term side Effects of NewerGeneration Antidepressants: SSRIS, Venlafaxine, Nefazodone, Bupropion, and Mirtazapine. Ann Clin Psychiatry 2002;14(3):175-82. [CrossRef]
22. Masand PS, Gupta S. Tolerability and Adherence Issues in Antidepressant Therapy. Clinical Therapeutics 2003;25(8): 2289-304. [CrossRef]

23. Lin E, Von Korff M, Katon W, Bush T, Simon GE, Walker $\mathrm{E}$, et al. The role of the primary care physician in patients' therapy. Med Care 1995;33(1):67-74. [CrossRef] 